\title{
Soil Fertility Management Based on Certified Organic Agriculture Standards - a Review
}

\author{
I. P. Sapinas ${ }^{1} \&$ L. K. Abbott ${ }^{2}$ \\ ${ }^{1}$ Gampaha, Sri Lanka \\ ${ }^{2}$ UWA School of Agriculture and Environment, and UWA Institute of Agriculture, The University of Western \\ Australia, Perth 6009, Australia \\ Correspondence: Inniyas P. Sapinas, Gampaha, Sri Lanka. E-mail: Inniyas.safinas8@ gmail.com
}

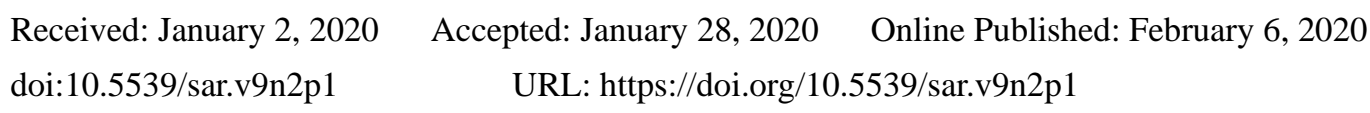

\begin{abstract}
In certified organic agricultural systems, soil nutrient status relies primarily on incorporation of organic matter and other specific inputs to meet requirements for phosphorus and micronutrients. Nutrient management strategies based on defined standards seek to maintain sufficient nutrient availability while minimizing potential losses. Although organic systems may result in lower levels of production than conventionally managed systems, sound soil nutrient management practices can minimize this gap. Certified organic standards are widely established globally, but traditional farming practices that resemble organic systems are also commonly used without adherence to a certified scheme. There is considerable debate about the efficiency of bio-amendments for use in organic farming due to their variability. Questions also persist about the sustainability of organic soil fertility management practices. The relevance of global variations among organic certification standards has not been a major consideration in research. Most soil improvement strategies focus on assessing the impact of particular amendments with less attention to a more holistic approach which integrates all components of the agricultural system. Research on implementation of practices based on certified organic standards highlights potential for multi-disciplinary, in-depth studies that identify combined impacts of organic management practices at a local scale. Standards developed at national level may not fully account for the breadth of soil types and environmental conditions. While soil improvement based on certified organic standards can contribute to socio-economic development and ecosystem services, local soil characteristics need to be considered in parallel with potential new avenues for sourcing nutrients, including organic matter management.
\end{abstract}

Keywords: organic agriculture, biological amendments, organic certification, sustainable farming

\section{Introduction}

Promotion of sustainable agricultural and agro-ecological practices supports conservation of genetic diversity and associated agricultural biodiversity (IPBES, 2019). Traditional farming practices have evolved over time, therefore integration of complex methods is widely practiced and well-adapted to local geo-climatic conditions (Vogl et al., 2005). Based on a range of traditional practices, organic farming is an integrated approach that seeks to sustain agro-ecosystems leading to achievement of sustainable goals in terms of food security (Mader et al., 2002; Reganold \& Watchter, 2016). Organic systems vary from strict, closed systems that rely on internal nutrient inputs, to systems that follow organic certification guidelines (Reganold \& Wachter, 2016). Organic agricultural practices include a focus on soil health, ecological processes and biodiversity without relying on use of synthetic chemical inputs.

It has been claimed that intensive agricultural management practices can cause soil degradation leading to reduced soil fertility (Malik et al., 2014). However, Timsina (2018) argued that there is insufficient scientific evidence to demonstrate that application of synthetic fertilizers at appropriated rates necessarily lead to destruction of soil properties such as structure and water retention capacity. A range of traditional farming practices are used as the basis of certified organic standards (Vogl et al., 2005). Certified organic farming emerged as a response to various impacts of conventional agriculture on the environment and their health consequences (Roos et al., 2018; Timsina, 2018). There are questions as to the sustainability of this production approach due to its reliance on natural fertility, and yields may be lower than in conventional systems (Baker, 2015; Roos et al., 2018). Although the long-term (>20 yr) study in Central Europe showed crop yield in organic 
systems was $20 \%$ lower than other systems, application of fertilizer, energy and pesticides were reduced by $34 \%$, 53\% and 97\% respectively (Mader et al., 2002). In contrast, yield of subsistence farming in (sub) tropical regions can out-perform conventional yield or equal that of systems that include legumes in temperate agriculture (e.g., Leifeld, 2012). Furthermore, examination of data from a long-term experiment in Pennsylvania indicated that grain yield over the first 5 years for corn was reduced during conversion to organic systems, but that yields after the transition period were similar (Pimentel et al., 2005).

Constraints introduced by certified organic farming standards may be advantageous compared with some conventional practices in terms of environmental and social benefits, but organic production may not be a sustainable option for the future of alternative agriculture (Baker, 2015). Sustainability assessment of organic systems is complex and general indices do not provide a complete image of their efficiency (Fess \& Benedito, 2018). The degree of sustainability depends on factors including regional climate, cultivation, soil conditions and topography, so farming methods need to be site-specific for a given organic system (Soumya, 2015). Organic farmers are exposed to financial risks during the conversion period to organic practices due to both reduced yield and price (Hanson et al., 2004). While disease, insects and weeds pose a high risk in organic farms in comparison to conventional farming due to a prohibition of use of most pesticides (Hanson et al., 2004), organic farmers may be at less risk health-wise because they use non-chemical control programs (Baker, 2015; Soumya, 2015).

Over recent decades, organic farming practices have become more widely respected globally, leading to significant increase in certified organic farms (Cong et al., 2005; Ramesh et al., 2010; Vogl et al., 2005). According to the recent survey by FiBL, a total of 69.8 million hectares were organically managed and 93 countries had organic regulation at the end of 2017, with a growth of $20 \%$ over the last year, and India has the largest number of organic producers followed by Uganda and Mexico (FiBL, 2019). However, millions of farmers use traditional farming methods evolved through generations without certification. In the least-developed countries, certified organic farming remains a limited option owing to poor knowledge of organic certification processes (Oelofse et al., 2010). The region with most organically-managed agricultural land is Oceania followed by Europe and Latin America (Figure 1). The global percentage of organic farmland is very low at only 1.4 percent but countries with a high share of their total farmland are Liechtenstein, Samoa and Austria at approximately $38 \%, 38 \%$ and $24 \%$ respectively (FiBL, 2019).

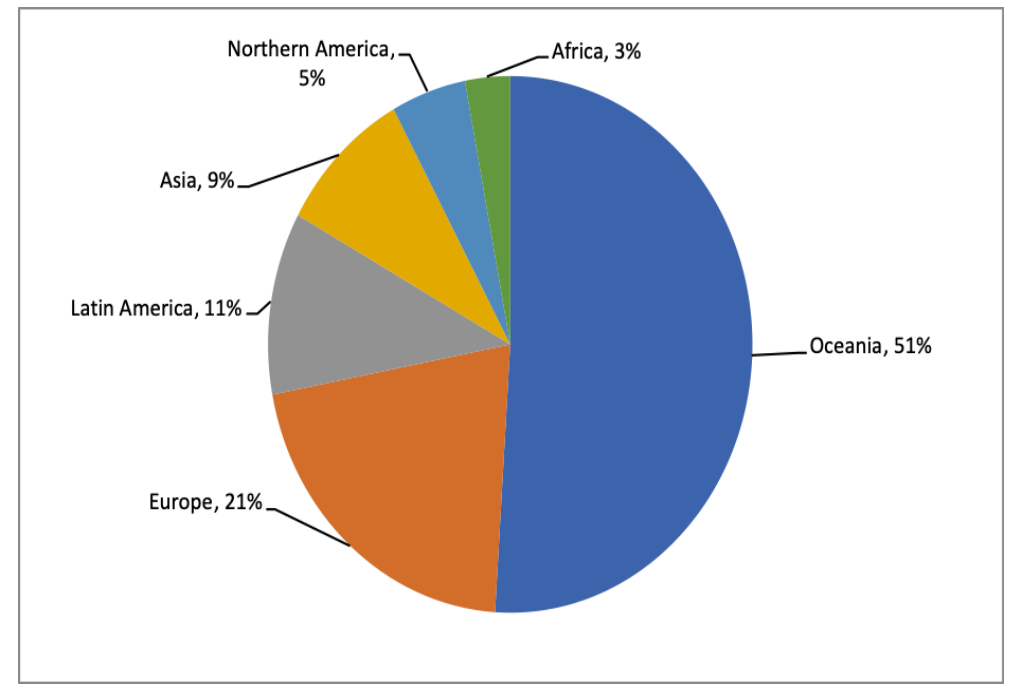

Figure 1. Proportion of organic agricultural land by region (FiBL, 2019)

The recent IPBES assessment report of land degradation and restoration indicated that many sustainable land management practices contribute to retention of soil organic matter and coincident nutrient cycling and that traditional farming methods can enhance soil carbon storage in managed landscapes (IPBES, 2019). In particular, the widespread use of reduced or no-till farming practices in intensive agriculture has led to great improvements in soil quality, including reduced erosion and retention of soil organic matter (Llewellyn \& Ouzman, 2019). Practices such as use of cover crops, green manures and intercropping can lead also improve soil conditions and yield, but they are less commonly used in intensive agriculture. With climate change emerging as one of the 
greatest threats to global agricultural production, land management practices must evolve further to be responsive to emerging economic fluctuations. Sustainable land use practices are indispensable to enhance climatic benefits via reducing greenhouse gas emission while co-benefiting from biodiversity (IPBES, 2019).

\section{Options for Soil Nutrient Management in Certified Organic Farming Systems}

Soil health refers to the degree to which dynamic properties are optimized within the constraints of the inherent properties of the soil (Schonbeck et al., 2017). Economic and ecological benefits of agriculture both rely on soil health, hence soil fertility maintenance is a fundamental basis in sustainable agriculture (Abawi \& Widmer, 2000; Bulluck et al., 2002; Saha et al., 2012). Soil quality is a function of both inherent and dynamic soil properties. Inherent properties include soil type, texture, depth to bedrock or other parent material and soil mineralogy (USDA, 2008). The more dynamic properties relate to soil biological fertility which has been defined as "the capacity of organisms living in the soil (microorganisms, fauna, and roots) to contribute to the nutritional requirements of plants and foraging animals for productivity, reproduction, and quality (considered in terms of human and animal wellbeing) while maintaining biological processes that contribute positively to the physical and chemical state of the soil" (Abbott \& Murphy, 2003). As soil properties respond to management practices (Karlen, 2003), the dynamic nature of soil biological properties is particularly influenced by addition of organic matter, tillage, nutrient management and plant rotation cycles (Schonbeck et al., 2017). Thus, soil performance in organic systems is highly influenced by crop and environmental conditions (Seufert et al., 2012).

Organic agricultural management practices range from small to large scale production (Reganold \& Wachter, 2016) and are generally based on farming practices that enhance soil quality through rotation of crops, inclusion of cover cropping and organic inputs, and reduced tillage (Fess \& Benedito, 2018). Soil enriched with nutrients from sources other than those which have undergone industrial transformations during their production can help to counteract climate change by enhancing soil carbon sequestration (Cong et al., 2005). Organic farming practices depend on complex integrated biological systems to sustain production. Effective nutrient management in organic farming systems needs to address immediate nutrient requirements, while maintaining and improving soil fertility in the longer term (Shepherd et al., 2006). This involves facilitation of complex inter-connected biological and physiochemical soil functions leading to a gradual supply of nutrients (Wortman et al., 2017) in contrast to focusing on nutrient provision at sowing (Fess \& Benedito, 2018). Changes in soil properties can vary with climatic conditions, soil type, crop rotation, and the duration of the amendment period (Clark et al., 1998). A decrease in the amount of organic inputs results in a decline in organic matter content of soil, thereby reducing available organic substrate for soil organisms with consequent disruption of essential soil functions, especially nutrient cycling (Santos et al., 2015; Miransari, 2013) and soil aggregation (Biswas et al., 2014; Jiao et al., 2006).

The primary characteristics of well-managed soil under organic farming practices include supply of nutrients from permitted sources based on certification standards, reduced water loss, resilience to environmental stress and resistance to pests and pathogens (Figure 2). However, there are ongoing arguments about the efficacy of biological amendments in improving soil fertility (e.g., Timsina, 2018). Biological amendments influence plant growth in different ways, and their modes of action vary from direct impact on plant physiology to indirect effects via their contributions as a soil conditioner or via cumulative impacts (Abbott et al., 2018). The application of organic matter into the soil in the form of bio-amendments provides a range of benefits including provision of nutrients, soil aggregation, enhanced water retention capacity, improved CEC, lower bulk density, protection against erosion and overall enhancement of microbial growth and their functions (Bulluck et al., 2002; Ferreras et al., 2006; Tejada et al., 2006). However, it has been claimed that while biological inputs benefit soil physical properties under aerobic conditions, they are less significant in anaerobic soil conditions such as those associated with soil submergence (e.g., during land preparation for paddy rice (Timsina, 2018)) may lower $\mathrm{pH}$ and reduce mineralization. Examples of use of different soil organic materials in organic production systems (Table 1) highlight the diversity of sources of biological inputs permitted by certification standards, mostly locally sourced, which differ greatly in their origin and nutrient status. Furthermore, the responses to their application to soil will vary with local soil and environmental conditions. Therefore, there is a greater degree of variation in inputs used in organic farming systems than in more conventional systems, and organic certification standards need to take this into account. Current certification standards for use of biological amendments differ to varying extents from country to country (Table 2), but while these differences may be based on regional experience, generalized standards may not always be appropriate locally (see Zikeli et al., 2017). For this reason, some certification constraints may not necessarily be locally appropriate, depending on the situation. 


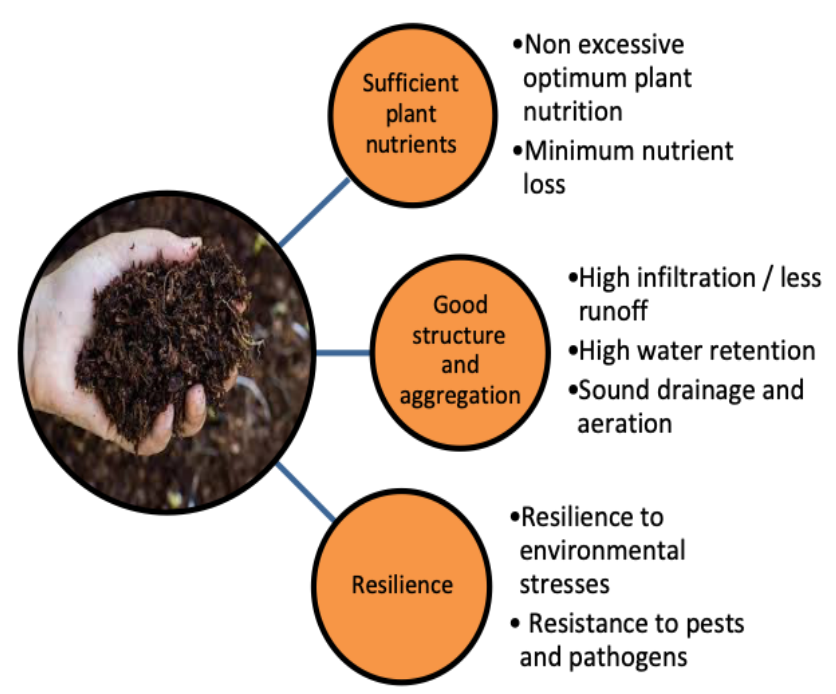

Figure 2. Characteristics of healthy soil in organic farming systems: structural factors and tactical management strategies diversify organic systems to sustain organic soil characteristics (Reganold \& Wachter, 2016; Schonbeck et al., 2017)

Table 1. Examples of impacts of biological amendments on soil characteristics (reported from research studies)

\begin{tabular}{|c|c|c|c|c|}
\hline $\begin{array}{l}\text { Amendment } \\
\text { (Reference) }\end{array}$ & Location & $\begin{array}{l}\text { Experimental } \\
\text { design }\end{array}$ & $\begin{array}{l}\text { Soil parameters } \\
\text { measured }\end{array}$ & Results \\
\hline \multirow{4}{*}{$\begin{array}{l}\text { Fresh cattle manure } \\
\text { (Whalen et al., 2000) }\end{array}$} & \multirow{4}{*}{$\begin{array}{l}\text { Peace River } \\
\text { region, Alberta, } \\
\text { Canada }\end{array}$} & \multirow{4}{*}{$\begin{array}{l}0,10,20,30 \\
40 / \mathrm{kg}\end{array}$} & $\mathrm{pH}$ & Immediate increase in soil $\mathrm{pH}$. \\
\hline & & & Mineral N & Immediate increase disappeared by $8 \mathrm{w}$. \\
\hline & & & $\mathrm{P}, \mathrm{K}, \mathrm{Ca}$ & Higher in amended soil. \\
\hline & & & CEC & Not affected. \\
\hline \multirow{3}{*}{$\begin{array}{l}\text { Cattle manure } \\
\text { (Nyamangara et al., 2001) }\end{array}$} & \multirow{3}{*}{$\begin{array}{l}\text { Harare, } \\
\text { Zimbabwe }\end{array}$} & \multirow{3}{*}{$\begin{array}{l}37.5 \mathrm{Mg} / \mathrm{ha} \text { in } \\
\text { year } 1 ; 12.5 \\
\mathrm{Mg} / \mathrm{ha} / \mathrm{yr} \text { for } 3 \mathrm{yr}\end{array}$} & Aggregate stability & Increase in soil structure stability. \\
\hline & & & Water retention & Water retention improved in first year. \\
\hline & & & Total organic $\mathrm{C}$ & $\begin{array}{l}\text { Increase in organic } \mathrm{C} \text { for manure } \\
\text { application of } 37.5 \mathrm{Mg} / \mathrm{ha} \text {. }\end{array}$ \\
\hline \multirow{4}{*}{$\begin{array}{l}\text { Several sources of } \\
\text { vermicompost } \\
\text { (Ferreras et al., 2006) }\end{array}$} & \multirow{4}{*}{$\begin{array}{l}\text { Vertic } \\
\text { Argiudoll, } \\
\text { Zavalla, } \\
\text { Argentina }\end{array}$} & \multirow{4}{*}{$\begin{array}{l}10 \text { and } 20 \mathrm{Mg} / \mathrm{ha} \\
(\mathrm{dw})\end{array}$} & $\mathrm{pH}$ & Increased. \\
\hline & & & $\begin{array}{l}\text { Water stable } \\
\text { aggregates (WS) }\end{array}$ & $\begin{array}{l}\text { Increased in amended soil at a rate of } \\
20 \mathrm{Mgha}^{-1} \text {. }\end{array}$ \\
\hline & & & $\begin{array}{l}\text { Ethanol stable } \\
\text { aggregates (Es) }\end{array}$ & Increased. \\
\hline & & & Microbial respiration & $\begin{array}{l}\text { Increased rate of microbial respiration } \\
\text { associated with one of the } \\
\text { vermicomposts. }\end{array}$ \\
\hline \multirow[t]{3}{*}{$\begin{array}{l}\text { Biodynamic fertilizers } \\
\text { (Aparna et al., 2014) }\end{array}$} & \multirow[t]{3}{*}{$\begin{array}{l}\text { Dhaban, } \\
\text { Rajastan }\end{array}$} & \multirow[t]{3}{*}{$\begin{array}{l}\text { biodynamic } \\
\text { fertilizers } \\
\text { compared with } \\
\text { conventional } \\
\text { management }\end{array}$} & $\begin{array}{l}\mathrm{pH}, \mathrm{EC}, \text { Water holding } \\
\text { capacity }\end{array}$ & $\begin{array}{l}\text { Water holding capacity increased in } \\
\text { orchard and organic systems: } 2.8 \% \\
\text { increase in organic cropping and } 1.9 \% \\
\text { in orchards. }\end{array}$ \\
\hline & & & Organic C & $\begin{array}{l}\text { Increase in organic carbon: organic } \\
\text { cropping }(0.2 \%) \text {; orchards }(0.4 \%)\end{array}$ \\
\hline & & & Available N, P, & $\begin{array}{l}\text { Ammonium N (ppm): Conventional } \\
\text { cropping (12.2) organic cropping }(24.0)\end{array}$ \\
\hline Composted cotton gin trash, & Virginia and & & $\mathrm{Ca}, \mathrm{Mg}, \mathrm{K}, \mathrm{Mn}, \mathrm{B}$, soil & Ca concentration increased 2-fold within \\
\hline Composted yard waste and & Maryland, USA & & $\mathrm{pH}$ & $2 \mathrm{yr}$. \\
\hline (Bulluck et al., 2002) & & & & $\begin{array}{l}\text { increased in comparison to synthetic } \\
\text { amendments. Soil pH increased with } \\
\text { organic amendments. }\end{array}$ \\
\hline
\end{tabular}


Nitrogen supplied via biological fixation is generally more common in organic systems than under conventional practices (Niggli \& Fliessbachn, 2008). Organically managed soils can be characterized by an increased pool of potentially mineralizable nitrogen compared to soil under conventionally managed practices (Fess \& Benedito, 2018). The combination of soil characteristics enhanced through organic management can result in a more tightly coupled nitrogen-cycle leading to reduced nitrogen losses via denitrification and leaching. An experiment conducted in Germany examining the impact of organic amendments on nitrogen-availability showed short-term release was minimal, but in the longer-term, nitrogen-use efficiency increased considerably (Gutser et al., 2005). In addition to provision of nitrogen, a wide range of biological amendments can provide sources of other plant nutrients, including $\mathrm{P}$ and $\mathrm{K}$ via mineralization, which are only available to a limited extent from rock minerals permitted for use in organic systems (Abbott \& Manning, 2015). Biological amendments can also stabilize soil $\mathrm{pH}$ and reduce nitrate runoff (Bulluck et al., 2002; Whalen et al., 2000).

\subsection{Animal Manure}

Manures are generally permitted for use in national organic certification standards, but there are some situations where constraints apply (Table 2). For example, in the Australian Standard, when manure is applied to cropping systems it must be composted or followed by at least two green manure crops. In Vietnam, the organic standard stipulates that animal manure from outside the farm must be hot-composted prior to application but urban waste compost is prohibited. Furthermore, the nutrient content of manures from different sources can differ considerably (Table 3), which introduces additional complexity when developing generalized organic certification standards.

Dairy manures are widely used as a nutrient source to improve the soil condition and stimulate crop growth (Ajmal et al., 2018; Eghball, 2000; Nyamangara et al., 2001; Whalen et al., 2000). Advocates of manure application claim that a range of chemical and physical properties including soil organic matter, bulk density, soil aggregate stability, infiltration capacity, water retention ability, hydraulic conductivity and surface crusting are significantly affected by manure inclusion (Whalen et al., 2000). However, nutrient content of manure depends on animal diet, manure age, breeding material type and storing conditions (Eghball et al., 2002; Timsina, 2018). In terms of manure application rates, nutrient budgeting is often valuable to ensure that the appropriate nutrient level is maintained in order to prevent extremes of environmental contamination (Wortman et al., 2017). Cattle manure can improve soil conditions, including where erosion is a problem (Whalen et al., 2000). Generally, it is expected that long-term manure application in organic farming may increase microbial biomass carbon (Joergensen et al., 2010).

The amount manure that needs to be applied is greatly influenced by manure composition, soil nutrient availability, crop type and environmental conditions (Eghball et al., 2002). Experiments on effects of animal manure on organic tomato farming system in coastal sandy soil in Clinton, USA showed a significant increase in extractable carbon (36-54mg kg $\mathrm{mg}^{-1}$ ), extractable nitrogen (3-15 $\left.\mathrm{mg} \mathrm{kg}^{-1}\right)$ and microbial biomass carbon (191-195 $\mathrm{mg} \mathrm{kg}^{-1}$ ) over a period of two years (Cong et al., 2005). The effect of cattle manure on soil $\mathrm{pH}$ is influenced by manure composition and soil characteristics (Whalen et al., 2000). Solid manure contains most of its nitrogen in an organic form, but poultry manure can have a significant amount of ammonium, leading to loss after surface application (Hue \& Silva, 2000).

The C:N ratio is a decisive factor determining the short-term nitrogen availability; animal manure may contain limited nitrogen levels in organic matter $(\mathrm{C}: \mathrm{N}>15)$ and immobilization further reduces its availability (Gutser et al., 2005). Manure with a high C:N ratio ( $>25)$ is likely to immobilize nitrogen and stimulate a flush of growth by bacteria and fungi (e.g., in bedded manures (Wander, 2019)). Research conducted in Alberta, Canada showed nitrate and ammonium concentrations in manure-amended soil declined after 8 weeks of incubation due to immobilization and /or denitrification, indicating that manure application was not further effective after an 8-week incubation period (Whalen et al. 2000). A study of nitrogen release from organic sources in East Lansing, USA, showed that the mineralization rate of chicken manure was rapid in the first week after application, but nitrogen release reached a plateau phase between 8 to 12 weeks (Agehara \& Warncke, 2005). However, a negative consequence of cattle manure application involved burning plant foliage and roots due to its high ammonium content (Ajmal et al., 2018). Cattle manure application needs to be managed carefully to mitigate nitrogen loss via greenhouse gas emission and contamination with aquatic resources via surface runoff leading to excessive nitrogen accumulation. Although nitrogen and phosphorus transport from manure applied to soil has been well reported, their contribution to soil aggregate fractions and stability in alleviating soil erosion less is well quantified (Whalen et al., 2001). Chicken manure can have a high salt content which can burn in plants if applied in high quantities (Hue \& Silva, 2000). Consequently, it is important to optimize and manage manure application to maintain soil fertility. Use of manure from a range of sources with a high ratio of $\mathrm{C}$ : $\mathrm{N}$ may be 
more effective in organic farming systems rather than simply increasing the application rate (Ren et al., 2014).

Table 2. Examples of organic materials (manures and composts) that are permitted for use by a range of national organic certification standards

\begin{tabular}{|c|c|c|}
\hline Organic Standard & Animal Manure & Compost \\
\hline $\begin{array}{l}\text { Australia (National standards } \\
\text { for organic and bio-dynamic } \\
\text { produce, 2016) }\end{array}$ & $\begin{array}{l}\text { Must be composted or application } \\
\text { should be followed by at least two green } \\
\text { manure crops in cropping systems. }\end{array}$ & $\begin{array}{l}\text { In accordance with Australian } \\
\text { standards } 4454-1999 \text { or } \\
\text { recognized standards. }\end{array}$ \\
\hline $\begin{array}{l}\text { India (National programme } \\
\text { for organic production, 2005) }\end{array}$ & $\begin{array}{l}\text { Slurry, urine, farmyard and poultry } \\
\text { manure from organically managed farms } \\
\text { are permitted, while outside sources are } \\
\text { restricted. Factory farming sources are } \\
\text { not permitted. }\end{array}$ & $\begin{array}{l}\text { Compost made from C- based } \\
\text { residues and household wastes are } \\
\text { restricted. }\end{array}$ \\
\hline $\begin{array}{l}\text { New Zealand (Organic } \\
\text { production rules, 2019) }\end{array}$ & $\begin{array}{l}\text { Not from animals fed feed with GMO or } \\
\text { antibiotics. Must be adequately } \\
\text { dehydrated. Microbial risk to be } \\
\text { managed. }\end{array}$ & $\begin{array}{l}\text { Composted or anaerobically } \\
\text { fermented vegetable and animal } \\
\text { household waste is permitted. }\end{array}$ \\
\hline $\begin{array}{l}\text { Canada (Organic production } \\
\text { systems, General Principals } \\
\text { and Management Standards, } \\
\text { 2008) }\end{array}$ & $\begin{array}{l}\text { Animal matter including liquid manure } \\
\text { and slurry obtained organic production is } \\
\text { permitted. Sufficient warm and moisture } \\
\text { is required to ensure active bio-oxidation } \\
\text { to when applied. Processed animal } \\
\text { manure by dehydration or specified } \\
\text { chemical processes. }\end{array}$ & $\begin{array}{l}\text { Composted animal matter and } \\
\text { plant. }\end{array}$ \\
\hline $\begin{array}{l}\text { Japan (Japan organic and } \\
\text { natural food association, } \\
\text { 2019) }\end{array}$ & $\begin{array}{l}\text { Manure should be composted and } \\
\text { matured for at least ninety (90) days and } \\
\text { fully cooled down. Methane fermented } \\
\text { digestive liquid (except for composted } \\
\text { sludge) is permitted. }\end{array}$ & $\begin{array}{l}\text { Fully matured compost obtained } \\
\text { on farm preferred. Organic matter } \\
\text { and fertilizers from outside should } \\
\text { be less than } 50 \% \text {. }\end{array}$ \\
\hline $\begin{array}{l}\text { Vietnam (PGS operation } \\
\text { manure for producers, 2009) }\end{array}$ & $\begin{array}{l}\text { Animal manure from outside the farm } \\
\text { must be hot composted. Urban waste } \\
\text { compost is prohibited. }\end{array}$ & $\begin{array}{l}\text { The use of synthetic fertilizers } \\
\text { and plant growth regulators } \\
\text { prohibited. Urban waste is not } \\
\text { allowed for composting. }\end{array}$ \\
\hline $\begin{array}{l}\text { Ireland (The Organic Trust } \\
\text { Ltd standards for organic food } \\
\text { and farming in Ireland, 2006) }\end{array}$ & $\begin{array}{l}\text { Farmyard manure, dried farmyard } \\
\text { manure and dehydrated poultry manure } \\
\text { are permitted. All manures should be hot } \\
\text { composted. Liquid animal excrements } \\
\text { (slurry, urine) need to be used after } \\
\text { controlled fermentation or appropriate } \\
\text { dilution. }\end{array}$ & $\begin{array}{l}\text { Composted animal excrements } \\
\text { are allowed (not from factory } \\
\text { farm). Composted household } \\
\text { waste allowed with conditions. }\end{array}$ \\
\hline $\begin{array}{l}\text { Uganda (Uganda organic } \\
\text { standards, 2006) }\end{array}$ & Permitted. & Permitted. \\
\hline $\begin{array}{l}\text { Austria (BIO AUSTRIA, } \\
\text { 2006) }\end{array}$ & $\begin{array}{l}\text { Manure, slurry and urine must not be } \\
\text { applied as top treatment to berry plants. } \\
\text { Farmyard manure and dried farm yard } \\
\text { manure are allowed. Liquid animal } \\
\text { excrements only from organic origin. }\end{array}$ & $\begin{array}{l}\text { Sewage sludge compost is } \\
\text { banned. Composted household } \\
\text { waste is allowed. }\end{array}$ \\
\hline $\begin{array}{l}\text { Tanzania (Tan Cert, Tanzania } \\
\text { organic certification } \\
\text { association, 2003) }\end{array}$ & Permitted. & Permitted. \\
\hline
\end{tabular}

National certification standards for organic farming state the permitted use of manure (Table 2), but in addition to the organic standards, some countries impose restrictions on manure application owing to regional impacts on 
water quality (Wander, 2019). There may also be local restrictions for manure application during winter seasons in some countries. For example, the USA, Canada, Australia and New Zealand have diverse sets of directives at a sub-national, state or provincial level for restricting manure application (Liu et al., 2018). National Organic Programme (NOP) standards in the USA impose manure application restrictions with application rates not exceed "agronomic application rates", implying that the amount applied must be less than or equal to the requirements of the crop (Wander, 2019).

Table 3. Examples of nutrient content in different sources of manure demonstrating range in nutrient values

\begin{tabular}{|c|c|c|c|c|c|}
\hline Manure source & $\begin{array}{l}\text { Total C } \\
(\mathrm{g} / \mathrm{Kg}) \text { or } \%\end{array}$ & $\begin{array}{l}\mathrm{N}(\mathrm{g} / \mathrm{Kg}) \\
\text { or } \%\end{array}$ & $\begin{array}{l}\mathrm{P}(\mathrm{g} / \mathrm{kg}) \\
\text { or } \%\end{array}$ & $\begin{array}{l}\mathrm{K}(\mathrm{g} / \mathrm{kg}) \\
\text { or } \%\end{array}$ & Reference \\
\hline Poultry & 614 & 40.8 & 17.4 & 21.2 & Tejada et al., 2006 \\
\hline Poultry & $31 \%$ & $2.14 \%$ & $1.09 \%$ & $1.23 \%$ & Ghosh et al., 2004 \\
\hline Cattle & $26 \%$ & $0.73 \%$ (total) & $0.18 \%$ & $0.71 \%$ & Ghosh et al., 2004 \\
\hline Cattle & $44 \%$ & $2.79 \%(\mathrm{TKN})$ & 7.89 & 38.45 & Costa et al., 2014 \\
\hline Chicken & 428 & 13.4 & & & Ferreras et al., 2006 \\
\hline Chicken & & 29 & 8.6 & 14.0 & Abdellrazzag, 2002 \\
\hline Cattle & 249 & $\begin{array}{l}22.8 \text { (total) } \\
2.9 \text { (available) }\end{array}$ & $\begin{array}{l}7.0 \text { (total) } \\
5.2 \text { (available) }\end{array}$ & 21.5 (available) & Whalen et al., 2000 \\
\hline Cattle & 78 to 237 & $7.9 \approx 15.6$ & $3.2 \approx 4.0$ & & Eghball, 2000 \\
\hline Cattle & 84 & 9.3 & & & Nyamangara et al., 2001 \\
\hline Rabbit & 338 & 31.3 & & & Gale et al., 2006 \\
\hline Sheep & & 16 & 4.2 & 6.9 & Abdelrazzag, 2002 \\
\hline
\end{tabular}

\subsection{Compost}

Although compost use is relatively more costly than raw manure application, compost has the potential to reduce environmental impacts associated with manure management (Wang et al., 2004). In conventional practices, compost is often used as an additional nutrient source to synthetic fertilizers (Larney et al., 2006). Compost has gained increasing attention due to constraints to application of raw manure based on potential environmental impacts. Conversion of manure nutrients into more stable forms should reduce surface runoff and groundwater contamination (Larney et al., 2006). Compost maturity is the key factor that affects its quality and nutrient composition. Composting process enhances organic matter stabilization and limit mineral nitrogen content (Gutser et al., 2005). Composting can reduce the rate of nitrogen release from manure (by approximately 50\%) by converting it into more stable biological forms (Wander, 2019). Wasted organic biomass, including crop residues, decomposing plant debris, weeds and surplus fodder can be utilized in composting. Compost is receiving renewed attention worldwide in restoration of disturbed land and to address environmental issues particularly waste management (Wiseman et al., 2012; Azim et al., 2018). During the composting process, microbial processes lead to a substantial loss of carbon. At the early stage of composting, inorganic nitrogen is present as $\mathrm{NH}_{4}-\mathrm{N}$ but during the latter stages $\mathrm{NO}_{3}-\mathrm{N}$ increases due to nitrification (Larney et al., 2006). Hence, lower ratios of $\mathrm{NH}_{4}-\mathrm{N}: \mathrm{NO}_{3}-\mathrm{N}$ indicate the maturity of the compost (Larney et al., 2006). Compost can be further enriched with the inclusion of potentially beneficial microorganisms such as phosphate solubilizers, $\mathrm{N}_{2}$ fixers and biocontrol agents (Hossain et al., 2017; Miransari, 2013). In comparison to manure, compost has a lower potential to degrade water quality and is likely to contain fewer pathogens (Wander, 2019). Disadvantages of composting include nutrient and carbon loss during the composting process, and associated odor (Eghball, 2000). Composting standards have been introduced to improve the quality and consistency of compost and these are independent of organic certification standards. Several countries in Europe have accredited standards for compost that address heavy metal contamination, organic matter characteristics, moisture, application rates and phytotoxicity (Brinton, 2000).

\subsection{Vermicompost}

Vermicomposting involves a simple biological process in which organic wastes are converted into stable products by earthworms (Rao et al., 2015; Saranraj \& Stella, 2012). Vermicomposting is distinguished from composting primarily in terms of the optimum temperature and dominant microbial communities present during the active stages of the composting process. Composting is dominated by thermophilic bacteria while mesophilic bacteria and fungi play an important role during the active phase of vermicomposting (Saranraj \& Stella, 2012). Vermicompost generally has a more homogenous structure and is likely to contain higher concentrations of organic acids such as humic and fulvic acids than most composts (Saranraj and Stella, 2012). Soils enriched with 
vermicompost have similar beneficial effects to those of compost. In addition to enhancing soil organic carbon, vermicompost may improve soil fertility by stimulating enzyme and hormone functions leading to plant growth stimulation (Elena, 2016; Gopal et al., 2009; Padmavathiamma et al., 2008). Vermicomposting reduces the C:N ratio to a greater extent than the typical composting process and nutrient content and physio-chemical conditions are improved due to feeding of waste by earthworms leading to bio-oxidation, turning, fragmentation and aeration with potential for formation of stabilized humus-like substances (Saranraj \& Stella, 2012).

\subsection{Compost Teas}

The technique of compost tea preparation involves steeping or brewing compost material in water via various methods. There is increasing interest in compost teas from both conventional and organic growers as an option which has potential to enhance microbial activity, soil nutrient retention and extraction and suppress disease (e.g., Pane et al., 2019). However, it is not a precise process because of the wide range of inputs and local conditions which influence development of microbial communities during the incubation period. A comparative study conducted in Korea assessed the effect of aerated compost tea on several crops; aeration increased the population density of bacteria, but there was a reduced fungal population in the compost tea (Kim et al., 2015). In this study, the aerated compost tea prepared from an organic compost mixture of rice straw compost, vermicompost and Hinoki cypress bark increased shoot and root growth as well as crop yield. A wide range of ingredients is added to compost tea with potential to increase activity and growth of specific microorganisms and to provide micronutrients for plants. However, some additives are condition-specific and only certain microorganisms respond to their presence (Ingham, 2005). Composts teas are generally supported by certified organic standards but scientific experimentation aimed at understanding their efficacy is limited.

\subsection{Green Manuring}

Incorporation of green manures is a widely used bio-amendment technique in organic agriculture to enhance soil quality. This practice is strongly supported by organic certification standards. Application of green manure plants (e.g., Sesbania and Gliricidia) can provide a wide range of benefits to the soil including addition of nitrogen and increased organic carbon leading to enhanced physical and chemical attributes of the soil (Srinivasa et al., 2011). Legumes play a key role as soil agents to sustain soil health by enhancing soil biology, biological nitrogen fixation, maintaining soil organic carbon and nitrogen stocks (Meena \& Lal, 2018). In India, inclusion of legumes can provide 50-150kg N/ha in about 90 days (Rao et al., 2015). Application of legumes as a form of green leaf manuring can protect the soil surface from raindrops leading to enhanced infiltration, and reduced soil erosion (Meena \& Lal, 2018; Srinivasa et al., 2011). Ecological benefits of green leaf manuring with Gliricidia sepium include enhancement of soil organic carbon, provision of sufficient nitrogen, and reduced soil erosion (Meena \& Lal, 2018). Legumes incorporated within cropping systems have a potential to make positive impacts on soil via enhanced earthworm activities and as well as negative impacts associated with increasing some detrimental nematodes (Srinivasa et al., 2011). Mulching improves soil structure and creates a more favorable environment for growth of beneficial microorganisms (Biswas et al., 2014). Legumes used within organic rotations enhance soil nitrogen as residues degrade (Pimentel et al., 2005). Undersowing with cover crops has been investigated in combination with reduced tillage for weed suppression in organic production systems, but this practice was shown to have limited success when perennial weeds were the dominant in cereals (Salonen \& Ketoja, 2019).

\subsection{Non-biological Allowable Inputs}

In addition to biological inputs permitted by the various organic certification standards, a wide range of materials is permitted that addresses soil fertility related to micro-nutrients and other elements. For example, permitted amendments include minerals from natural sources such as calcium supplied as dolomite, gypsum or lime, clay minerals including bentonite, kaolin and attapulgite, magnesium from rock minerals, rock phosphate and phosphatic guano, potassium from rock minerals or as potassium sulphate and elemental sulphur. The extent to which some of these elements are available can be quite limited (Abbott \& Manning, 2015). Sourcing phosphorus is of particular concern (Løes et al. 2017). Ocean-derived products are a potential source of micronutrients in organic production and they generally comply with certification standards (Krishnamoorthy et al., 2019). In addition, a wide range of microbial inocula and microbial preparations are also permitted within most organic standards. The diverse nature of these permitted inputs provides a range of options that are alternatives to synthetic chemicals for overcoming nutrient deficiencies, plant disease, damage from insect and other pests, and weed infestation. Interactions between humic substances and microorganisms (Pukalchik et al., 2019) have potential to release a range of plant available nutrients which may be of value in organic production systems and are likely to meet most organic certification standards. However, variability in the chemistry of 
potential alternative sources of plant nutrients means that their modes of action, including their roles as biostimulants, are often not well understood (Abbott et al., 2018).

\section{Impact of Organic Inputs on Soil Properties}

Organic farming depends on the management of soil organic matter (Biswas et al., 2014; Gattinger et al., 2012), which is dictated by organic standards and certification processes (Table 2) and varies with the form of biological amendment (Table 3). Soil organic matter can be enhanced in soils managed according to organic practices (Clark et al., 1998) leading to improved soil structural properties. However, the soil's ability to retain stable carbon is also directly related to soil texture (Schonbeck et al., 2017). Crop rotation significantly influences carbon dynamics (Poyda et al., 2019). Soil organic matter provides a range of benefits including nutrients and substrates for soil organisms, optimization of physical conditions for plant growth, soil buffering and nutrient cycling (Abawi \& Widmer, 2000). Advocates of organic farming claim that organic systems have greater soil carbon levels leading to better soil quality and are more resistant to soil erosion (Reganold \& Watchter, 2016) although this can be site-specific. Nevertheless, while soil organic carbon can increase in organically managed systems (i.e. organic animal based and legume-based systems) compared to conventional systems (e.g., Pimentel et al., 2005), higher stabilized organic matter content and more efficient use of substrate is not a feature restricted to organically managed systems (Leifeld, 2018).

Soil water retention is an important hydrological parameter for indicating the soil condition. Water retention describes water availability to plants. In severe drought conditions, the yield in organic farming can be higher than equivalent conventional systems, owing to a higher water retention capacity in the soil (Reganold \& Watchter, 2016). Organic amendments generally improve soil water retention (Aparna et al., 2014; Srinivasa et al., 2011; Nyamangara et al., 2001). There can be a correlation between soil organic matter and capacity to retain water (Badha et al., 2017; Rawls et al., 2003) providing water repellence is not indicated. The texture of soil is an important factor influencing the potential of organic carbon in determining soil water retention. Water retention in coarse-textured soil is more strongly linked to changes in organic carbon than in fine-textured soils (Rawls et al., 2003). A steady increase in water holding capacity has been observed with every $1 \%$ increase in organic matter for both sandy soil and limerock in Florida (Bhadha et al., 2017).

Mineralization of organic materials is a key process for nutrient supply in organic farming, and this is primarily driven by soil microorganisms. Soil organisms form the biological basis of the soil in combination with plant roots, and both influence soil health. Organic farmers impose numerous practices to increase microbial diversity and activity (Reeve et al., 2016). While microbial communities are highly abundant in soil, they are also diverse and complex (Delgado-Baquerizo et al., 2016; Santos et al., 2015). Diversity of soil microbes indicates variation in biological organization which in turn can be linked to numerous processes and complex soil-microbe interactions (Santos et al., 2015; Torsvik \& Ovreas, 2002). Microbially-mediated processes have a vital role in recovering soil from disturbances during soil reclamation (Aparna et al., 2014; Santos et al., 2015). In addition to nutrient cycling, microbial processes influence soil stability, productivity and resilience. Numerous studies have highlighted the impact of spatial isolation and soil structure on microbial diversity (e.g., Torsvik \& Ovreas, 2002). Organic amendments significantly influence soil microbial communities (Aparna et al., 2014; Ferreras et al., 2006; Tejada et al., 2006; Wiseman et al., 2012). In an organically managed soil, mycorrhizal colonisation can be considerably higher than in conventionally managed systems (Mader et al., 2002; Ryan et al., 1994) and biological amendments can lead to improved soil physio-chemical properties (Abbott \& Manning, 2015; Bullock et al., 2002), which in turn impact on growth and functions of soil organisms (Cong et al., 2005; Pukalchik et al., 2019).

Soil $\mathrm{pH}$ significantly influences soil microbial composition and enzyme activities (Delgado-Baquerizo et al., 2016) and particle size greatly influences microbial occupation. Bacterial communities can colonise silt and clay particles with greater diversity than sand particles (Torsvik \& Ovreas, 2002). Diverse functional groups of soil microorganisms including nitrogen fixing bacteria (Azotobacter spp., Azospirillum spp. and Rhizobium spp.) and ammonifiers and nitrifiers play crucial roles in nutrient cycling. Biological amendments can enhance beneficial Trichoderma spp, while reducing pathogens (Phytophthora and Pythium) (Bulluck et al., 2002), but the number of nitrogen fixers in bulk soils does not necessarily increase (Aparna et al., 2014). Assessing the dynamics of microbial communities in soil is complex and there may not be a clear relationship between the abundance of key groups or species and the functions that they perform at any time (Mickan et al., 2018).

\section{Concluding Comments}

The history of organic farming practices extends over centuries and involves traditional best farming strategies based on ecological principles. Despite organic agricultural farming systems having many shortcomings, the 
number and the extent of organic farms have significantly increased over the recent decades owing to their potential to reduce use of chemicals and contribute to environmental and human health. Although biological amendments for soil fertility management in organic farming are broadly categorized, variation within each category is considerable. Therefore, it is difficult to precisely predict the impacts of amendments or their modes of action under some soil and environmental conditions. Short term research limits understanding the cumulative impact and effect over a range of seasonal conditions. Long-term field research has potential to address knowledge gaps that are not evident from short-term studies. There is also a need for collaborative on-farm testing that links knowledge of researchers and farmers (Pauli et al., 2018). A key factor for consideration into the future is matching organic certification standards to local soil conditions and appropriate use of combinations of biological inputs (Zikeli et al., 2017). There is a need to consider whether the organic standards take into account the availability of new resources which have potential to sustain efficient organic production systems but which might currently not be permitted (Løes and Adler, 2019). Further discussion at the interface of regulation of nutrients from waste materials and strict certification standards is suggested within the framework of organic agriculture principles (Løes et al., 2017).

Large scale organic agriculture requires support from research dedicated to agro-ecological methods of soil fertility management (Badgley et al., 2007). The recent report of the Intergovernmental Science Policy Platform on Biodiversity and Ecosystem Services (IPBES, 2019) emphasized the importance of identification of synergies between sustainable agricultural practices that enhance soil quality, thereby improving soil productivity and other ecosystem functions and services including soil carbon sequestration and water quality regulation. It is conceivable that more research dealing with novel strategies to improve soil health via biological amendments will be an important topic in the future in terms of sustainable environmental management in agriculture. Although theoretical evidence exists, there is a shortage of field-based evidence to understand how bio-amendments work to improve soil fertility (Abbott et al., 2018). Advances in understanding the relative importance and association of soil physio-chemical properties and microbial function is vital to improve further management strategies for maintaining ecosystem functions (Delgado-baquerizo et al., 2016).

The sustainability of organic farming remains controversial with respect to greenhouse gas emissions. Organic farming requires more land, therefore contributes to higher emissions in comparison to conventional agriculture for equivalent production levels (Smith et al., 2019). It is expected that profitable use of degraded agro-ecosystems through sound restoration strategies would have significant contribution to the agricultural productivity in future to meet the challenges of sustainable production with anticipated climate extremes. Therefore, soil management through environmentally friendly strategies needs to be intensified to ensure the food security for the growing population. Soil biological properties are the most dynamic characteristics of soil, which have a rapid response to land use changes (Lal, 2016). Better understanding of soil microbial diversity, function and interactions in an organic agricultural context is vital for identifying soil health improvement strategies which may serve as an indicator to assess overall soil fertility (Tilak et al., 2005).

Although organic farming can account for lower yield in comparison to conventional systems, sustainable levels of production can be reached compared to conventional practices (Reganold \& Wachter, 2016) with reduced input costs. There is a need for multi-disciplinary research to identify combined impacts of organic management techniques within the constraints of national certification standards. Field-scale evidence of how biological amendments contribute within the constraints of the certification standards is required based on soil type and environmental conditions. This could be done in collaboration with farmers. During the period of conversion to certified organic agricultural practices, transformation of soil conditions over the transition period needs to be assessed and quantified in terms of soil physio-chemical and biological properties. Finally, although organic systems can be relatively economical, further investigation of permitted soil fertility-building strategies is required to continuously re-align certified organic standards with local conditions and changing availability of sources of nutrients (Løes and Adler, 2019).

\section{References}

Abawi, G. S., \& Widmer, T. L. (2000). Impact of soil health management practices on soil borne pathogens, nematodes and root disease of vegetable crops. Applied Soil Ecology, 15, 37-47. https://doi.org/10.1016/S0929-1393(00)00070-6

Abbott, L. K., Macdonald, L. M., Wong, M. T. F., Webb, M. J., Jenkins, S. N., \& Farrell, M. (2018). Potential roles of biological amendments for profitable grain production: A review. Agriculture Eecosystems and Environment, 256, 34-50. https://doi.org/10.1016/j.agee.2017.12.021

Abbott, L. K., \& Manning, D. A. C. (2015). Soil health and related ecosystem services in organic agriculture. 
Sustainable Agriculture Research, 4, 116-125. https://doi.org/10.5539/sar.v4n3p116

Abbott, L. K., \& Murphy, D. V. (2003). What is Soil Biological Fertility? in Soil Biological Fertility: A Key to Sustainable Land in Agriculture, Kluwer Academic Publishers, The Netherlands (reprinted 2007 by Springer). pp. 1-15. https://doi.org/10.1007/978-1-4020-6619-1

Abdelrazzag, A. (2002). Effect of chicken manure, sheep manure and inorganic fertilizer on yield and nutrient uptake by onion. Pakistan Journal of Biological Sciences, 5(3), 266-268.

https://doi.org/10.3923/pjbs.2002.266.268

Agehara, S., \& Warncke, D. D. (2005). Soil moisture and temperature effects on nitrogen release from organic nitrogen sources. Soil Science Society America Journal, 69, 1844-1855. https://doi.org/10.2136/sssaj2004.0361

Ajmal, M., Ali, H. I., Saeed, R., Akthar, A., Tahir, M., Mehboob, M. Z., \& Ayub, A. (2018). Research and reviews: biofertilizers as an alternative for chemical fertilizers. Journal of Agriculture and Allied Science, 7, $1-5$.

Aparna, K., Pasha, M. A., Rao, D. L. N., \& Krishnaraj, P. U. (2014). Organic amendmentsn as ecosystem engineers: Microbial biochemical and genomic evidence of soil health improvement in a tropical arid zone field site. Ecological Engineering, 71, 268-277. http://dx.doi.org/10.1016/j.ecoleng.2014.07.016

Azim, K., Soudi, B., Boukhari, S., Perissol, C., Roussos, S., \& Thami, A. I. (2018). Composting parameters and compost quality: a literature review. Organic Agriculture, 8, 141-158. https://doi.org/10.1007/s13165-017-0180-z

Badgley, C., Moghtader, J., Quintero, E., Zakem, E., Chappell, M. J., Vazquez, K. A., Samulon, A., \& Perfecto, I. (2007). Organic Agriculture and global food supply. Renewable Agriculture and Food Systems, 22(2), 86-108. https://doi.org/10.1017/S1742170507001640

Baker, K. (2015). The truth about organic: Sustainability practice and perception. Undergraduate honor thesis 826. University of Colorado. pp. 73-75. Retrieved from https://scholar.colorado.edu/honr_theses/826

Biswas, S., Ali, M. N., Goswami, R., \& Chakraborthy, S. (2014). Soil health sustainability and organic farming: A review. Journal of Food Agriculture and Environment, 12(3 \& 4), 237-243.

Bhadha, J. H., Capasso, J. M., Khatiwada, R., Swanson, S., \& LaBorde, C. (2017). Raising soil organic matter content to improve water holding capacity. IFAS Extension, University of Florida. SL 447. pp. 1-5.

Bio-Austria, (2006). Regulations for organic farming in Austria. Association for promoting organic farming. Linz. pp. 9-10. Retrieved from https://www.bio-austria.at/

Brinton, W. F. (2000). Compost standards and guidelines. Final report. Woods and Research Laboratory. USA. pp. 1-15.

Bulluck, L. R., Brosium, M., Evanylo, G. K., \& Ristaino, J. B. (2002). Organic and synthetic fertility amendments influence soil microbial, physical and chemical properties on organic and conventional farms. Applied Soil Ecology, 19, 147-160. https://doi.org/10.1016/S0929-1393(01)00187-1

Canadian General Standard Board. (2006). Organic production systems: General Principals and Management Standards. Gatineau, Canada. pp. 9-10. Retrieved from https://www.certifiedorganic.bc.ca/standards/docs/CAN-CGSB-32.310-2015E.pdf

Clark, M. S., Horwath, W. R., Shennan, C., \& Scow, K. M. (1998). Changes in soil chemical properties resulting from organic and low input farming practices. Agronomy Journal, 90, 662-671. https://doi.org/10.2134/agronj1998.00021962009000050016x

Cong, T., Ristaino, J. B., \& Hu, S. (2006). Soil microbial biomass and activity in organic tomato farming system: Effects of organic inputs and straw mulching. Soil Biology and Biochemistry, 38(2), 247-255. http://dx.doi.org/10.1016/j.soilbio.2005.05.002

Costa, M. S. S. M., Costonaro, T., Costa, L. A. M., Rozatti, M. A. T., Carneiro, L. J., Pereira, D. C., \& Lorin, H. E. F. (2014). Improving the nutrient content of sheep bedding compost by adding cattle manure. Journal of Cleaner Production, 86, 9-14. http://dx.doi.org/10.1016/j.jclepro.2014.08.093

Delgado-Baquerizo, M., Grinyer, J., Reich, P. B., \& Singh, B. K. (2016). Relative importance of soil properties and microbial community for soil functionality: insights from a microbial swap experiment. Functional Ecology, 30, 1862-1873. http://dx.doi.org/10.1111/1365-2435.12674 
Eghball, B. (2000). Nitrogen mineralization from field-applied beef cattle feedlot manure or compost. Soil Science Society America Journal, 64, 2024-2030. https://doi.org/10.2136/sssaj2000.6462024x

Eghball, B., Wienhold, B. J., Gilley, J. E., \& Eigenberg, R. A. (2002). Mineralization of manure nutrients. Journal of Soil and Water Conservation, 57(6), 470-473.

Elena, M. M. (2016). Vermicomposting efficiency and quality of vermicompost with different Bedding materials and worm food sources as Substrate. Research Journal of Agriculture and Forestry Sciences, 4(1), 1-13

Ferreras, L., Gomes, E., Toresani, S., Firpo, I., \& Rotondo, R. (2006). Effect of organic amendments on some physical, chemical and biological properties in a horticulture soil. Bioresource Technology, 97, 635-640. https://doi.org/10.1016/j.biortech.2005.03.018

Fess, T. L., \& Benedito, V. A. (2018) Organic vs conventional cropping sustainability: A comparative system analysis. Sustainability, 10, 272. http://dx.doi.org/10.3390/su10010272

FiBL. (2019). Global organic area reaches another all-time high. Media release February 13, 2019. pp. 1-12. Retrieved from http://www.organic-world.net/yearbook/yearbook-2019.html

Gale, E. S., Sullivan, D. M., Cogger, C. G., Bary, A. L., Hemphill, D. B, \& Myhre, E. A. (2006). Estimating plant available nitrogen release from manures, compost and specialty products. Journal of Environmental Quality, 35, 2321-2332. http://dx.doi.org/10.2134/jeq2006.0062

Gattinger, A., Muller, A., Haeni, M., Skinner, C., Fliessbach, A., Buchmann, N., ... Niggli, U. (2012). Enhanced topsoil carbon stock under organic farming. Proceedings of the National Academy of Sciences of the United States of America, 109(44), 18226-18231. https://doi.org/10.1073/pnas.1209429109

Ghosh, P. K., Ramesh, P., Bandyophadhyay, K. K., Tripathi, A. K., Hati, K. M., Misra, A. K., \& Acharya, C. L. (2004). Comparative effectiveness of cattle manure, poultry manure and phosphocompost and fertilizer-NPK on three cropping System. Bioresource Technology, 95(1), 77-83. http://dx.doi.org/10.1016/j.biortech.2004.02.011

Gopal, M., Gupta, A., Suni, 1. E., \& Thomas, V. (2009). Amplification of plant beneficial microbial communities during conversion of coconut leaf substrate to vermicompost by Eudrilus sp. Current Microbiology, 59, 15-20. http://dx.doi.org/10.1007/s00284-009-9388-9

Gutser, R., Ebertseder, T., Weber, A., Schraml, M., \& Schmidhalter, U. (2005). Short-term and residual availability of nitrogen after long term application of organic fertilizers on arable land. Journal Plant Nutrition and Soil Science, 168, 439-446. http://dx.doi.org/10.1002/jpln.200520510

Hanson, J. C., Dismukes, R., Chambers, W., Greene, C., \& Kremen, A. (2004). Risk and risk management in organic agriculture: View of Organic Farmers. The University of Maryland, College park. pp. 5-8. https://doi.org/10.1079/RAFS200482

Hossain, M. Z., Fragstein, P. V., \& Heb, J. (2017). Effect of Organic wastes on soil properties, plant growth and yield: A review. Scientia Agriculturae Bohemica, 48(4), 224-237. http://dx.doi.org/10.1515/sab-2017-0030

Hue, N. V., \& Silva, J. A. (2000). Organic soil amendments for sustainable agriculture: Organic sources of nitrogen, phosphorus and potassium. Plant nutrient management in Hawaii's soils. Chapter 15. pp. 133-144.

Ingham, E. R. (2005). The compost tea brewing manual. Fifth edition. Soil foodweb Inc. Oregon. pp. 1-11.

IPBES. (2019). Intergovernmental Science Policy Platform on Biodiversity and Ecosystem Services (2019). Plenary Report. Retrieved from https://www.ipbes.net/global-assessment-report-biodiversity-ecosystem-Services.

Jiao, Y., Whalen, J. K., \& Hendershot, W. H. (2006). No tillage and manure application increase aggregation and improve nutrient retention in a sandy loam soil. Geoderma, 134, 24-33. http://dx.doi.org/10.1016/j.geoderma.2005.08.012

Joergensen, R. G., Mader, P., \& Andreas, F. (2010). Long term effects on organic farming on fungal and bacterial residues in relation to microbial energy metabolism. Biology and Fertility of Soils, 46, 303-307. http://dx.doi.org/10.1007/s00374-009-0433-4

Joint Irish OCB Standards Committee (2006). The Organic Trust Ltd, Standards for Organic Food and Farming in Ireland. 4th edition. pp. 26-40. Retrieved from http://organictrust.ie/pdfs/standards.pdf

Karlen, D. L., Ditzler, C. A., \& Andrews, S. S. (2003). Soil quality: Why and how. Geoderma, 114, 145-156. 
http://dx.doi.org/10.1016/S0016-7061(03)00039-9

Kim, M. J., Shim, C. K., Kim, Y. K., Hong, S., J, Park, J. H., Han, E. J., Kim, J. H., \& Kim, S. C. (2015). Effect of aerated compost tea on the growth promotion of lettuce, soya bean and sweet corn in organic cultivation. Plant Pathology Journal, 31(3), 259-268. http://dx.doi.org/10.5423/PPJ.OA.02.2015.0024

Krishnamoorthy, R., Alshatwi, A. A., Subbarayan, S., Vadivel, B., Subbarayan Oeriyasamy, V., Al-Shuniaber, M. A., \& Athinarayanan, J. (2019). Impact of farm-made liquid organic nutrients jevamirtham and fish amino acid on growth and nutritional status in different season of Abelmoshus esculentus - a self-sustaibable field trial. Organic Agriculture, 9, 65-79. http://dx.doi.org/10.1007/s13165-018-0205-2

Lal, R. (2016). Soil health and carbon management: Review. Food and Energy Security, 5(4), 212-222. http://dx.doi.org/10.1002/fes3.96

Larney, F. J., Sullivan, D. M., Buckley, K. E., \& Eghball, B. (2006). The role of composting in recycling manure Nutrients. Canadian Journal of Soil Science, 86, 597-611. http://dx.doi.org/10.4141/S05-116

Liefeld, J. (2012). How sustainable is organic farming? Agriculture, Ecosystem and Environment, 150(2012), 121-122. http://dx.doi.org/10.1016/j.agee.2012.01.020

Liu, J., Kleinman, P. J. A., Aronsson, H., Flaten, D., McDowell, R. W., Bechmann, M., ... Veith, T. L. (2018). A review of regulations and guidelines related to winter manure application. Ambio, 47, 657-670. https://doi.org/10.1007/s13280-018-1012-4

Llewellyn, R., \& Ouzman, J., (2019). Conservation agriculture in Australia: 30 years on. In J. Pratley, \& J. Kirkegaard (Eds.), Australian Agriculture in 2020: From Conservation to automation (pp. 21-31). Australian Society of Agronomy. Retrieved from http://hdl.handle.net/102.100.100/192317?index=1

Løes, A. K., Bünemann, E. K., Cooper, J., Hörtenhuber, S., Magid, J., Oberson, A., \& Möller, K. (2017). Nutrient supply to organic agriculture as governed by EU regulations and standards in six European countries. Organic Agriculture, 7, 395-418. https://doi.org/10.1007/s13165-016-0165-3

Løes, A.-K., \& Adler, S. (2019). Increased utilization of renewable resources: Dilemmas for organic agriculture. Organic Agriculture, 9, 459-469. https://doi.org/10.1007/s13165-018-00242-2

Mader, P., Fliebach, A., Dubois, D., Gunst, L., Fried, P., \& Niggli, U. (2002). Soil fertility and biodiversity in organic farming. Science, 296(5573), 1694-1697. https://doi.org/10.1126/science.1071148

Malik, S. S., Chauhan, R. C., Laura, J. S., Kapoor, T., Abhilashi, R., \& Sharma, N. (2014). Influence of organic and synthetic fertilizers on soil physical properties. International Journal Current Microbiologu and Applied Sciences, 3(8), 802-810.

Meena, R. S., \& Lal, R. (2018). Legumes and Sustainable Use of Soils. In R. Meena, A. Das, G. Yadav, \& R. Lal (Eds.), Legumes for Soil Health and Sustainable Management. Springer, Singapore. https://doi.org/10.1007/978-981-13-0253-4_1

Mickan, B. S., Abbott, L. K., Fan, J.-W., Hart, M. M., Siddique, K. H. M., Solaiman, Z. M., \& Jenkins, S. N. (2018). Application of compost and clay under water-stressed conditions influences functional diversity of rhizosphere bacteria. Biology and Fertility of Soils, 54, 55-70. http://dx.doi.org/10.1007/s00374-017-1238-5

Ministry of Commerce and Industries (2005). National programme for organic production. 6th edition. New Delhi, India. pp. 158-162. Retrieved from http://www.apeda.gov.in/apedawebsite/organic/ORGANIC_CONTENTS/English_Organic_Sept05.pdf

Ministry of Primary Industries (2019). Organic production rules. Wellington, New Zealand. pp. 49-50. Retrieved from https://www.mpi.govt.nz/dmsdocument/38735-organic-export-requirement-organic-production.

Miransari, M. (2013). Soil microbes and the availability of soil nutrients. Acta Physiologiae Plantarum, 35, 3075-3084. https://doi.org/10.1007/s11738-013-1338-2

Niggli, U., \& Fliessbach, A. (2008). Organic farming and climate change. Research Institute of Organic Agriculture, FiBL. Frick, Switzerland. pp. 9-13. Retrieved from https://orgprints.org/13414/3/niggli-etal-2008-itc-climate-change.pdf

Nyamangara, J., Gotosa, J., \& Mpofu, S. E. (2001). Cattle manure effects on structural stability and water retention capacity of a granitic sandy soil in Zimbabwe. Soil and Tillage Research, 62, 157-162. https://doi.org/10.1016/S0167-1987(01)00215-X

Oelofse, M., Jensen, H. H., Abreu, L. S., Almeida, G. F., Araby, A., Hui, Q. U., \& Neergaard, A. D. (2010). A 
comparative study of farm nutrient budgets and nutrient flows of certified organic and non-organic farms in China, Brazil and Egypt. Nutrient Cycling in Agroecosystems, 87, 455-470.

http://dx.doi.org/10.1007/s10705-010-9351-y

Organic Industry Standards and Certification Committee. (2016). National standards for organic and bio-dynamic produce. Canberra, Australia. pp. 49-50. Retrieved

fromhttps://www.agriculture.gov.au/export/controlled-goods/organic-bio-dynamic/national-standard

Padmavathiamma, P. K., Li, L. Y., \& Kumari, U. R. (2008). An experimental study of vermi-biowaste composting for agricultural soil improvement. Bioresource Technology, 99, 1672-1681. https://doi.org/10.1016/j.biortech.2007.04.028

Pane, C., Spaccini, R., Piccolo, A., Celano, G., \& Zaccardelli, M. (2019). Disease suppressivenss of agricultural greenwaste composts as related to chemical and bio-based properties shaped by different on-farm composting methods. Biological Control, 137, 104026. https://doi.org/10.1016/j.biocontrol.2019.104026

Participatory Guarantee System (PGS) of organic products. (2010). Operation manual for producers: version 1.03. Vietnam. pp. 20-22.

Pauli, N., Abbott, L. K., Rex, R., Rex, C., \& Solaiman, Z. M. (2018). A farmer-scientist investigation of soil carbon sequestration potential in a chronosequence establishment of perennial pastures. Land Degradation and Development, 29, 4301-4312. http://dx.doi.org/10.1002/ldr.3184

Pimentel, D., Hepperly, P., Hanson, J., Douds, D., \& Seidel, R. (2005). Environmental, energetic and economic comparisons of organic and conventional farming systems. Bioscience, 55(07), 573-582. http://dx.doi.org/10.1641/0006-3568(2005)055[0573:EEAECO]2.0.CO;2.

Poyda, A., Wizemann, H.-D., Ingwersen, J., Eshonkulov, R., Hogy, P., Demyan, M. S., Kremer, P., Wulfmeyer, V., \& Streck, T. (2019). Carbon fluxes and budgets of intensice crop rotations in two regional climates of southwest Germany. Agriculture, Ecosystems and Environment, 276, 31-46. http://dx.doi.org/10.1016/j.agee.2019.02.011

Pukalchik, M., Kydralleva, K., Yaklmenko, O., Fedoseeva, E., \& Terekhova, V. (2019) Outlining the potential role of humic products in modifying biological properties of soil - A review. Frontiers in Environmental Science. https://doi.org/10.3389/fenvs.2019.00080

Ramesh, P., Panwar, N. R., Singh, A. B., Raman, S., Yadav, S. K., Shrivastava, R., \& Rao, A. S. (2010). Status of organic farming in India. Current Science, 98(09), 1190-1194.

Rao, A. S., Lenka, N. K., Biswas, A. K., \& Ramesh, K. (2015). Soil health enhancement: Issues and strategies. Indian Journal of Fertilizers, 11(4), 28-37.

Rawls, W. J., Pachepsky, Y. A., Ritchie, J. C., Sobecki, T. M., \& Bloodworth, H. (2003). Effect of soil organic carbon on soil water retention. Geodema, 11, 61-76. http://dx.doi.org/10.1016/S0016-7061(03)00094-6

Reeve, J. R., Hoagland, L. A., Villaba, J. J., Carr, P. M., Atucha, A., Cambardella, C., Davis, D. R., \& Delate, K. (2016). Organic farming soil health and food quality: Considering possible links. Advances in Agronomy, 137, 319- 368. http://dx.doi.org/10.1016/bs.agron.2015.12.003

Reganold, J. P., \& Wachter, J. M. (2016). Organic agriculture in the twenty- first century. Nature Plants, 15221. http://dx.doi.org/10.1038/nplants.2015.221

Ren, T., Wang, J., Chen, Q., Zhang, F., \& Lu, S. (2014). The effect of manure and nitrogen fertilizer application on soil organic carbon and nitrogen in a higher-input cropping system. PLoS ONE, 9(5), e97732. https://doi.org/10.1371/journal.pone.0097732

Roos, E., Mie, A., Wivstad, M., Salomon, E., Johansson, B., Gunnarsson, S., ... Watson, C. A. (2018). Risk and opportunities of increasing yields in organic farming: A review. Agronomy for Sustainable Development, 38, 14. https://doi.org/10.1007/s13593-018-0489-3

Russia to adopt new law on organics. (2019). Global agricultural information network. Gain report number RS:1823. Moscow. pp. 1-8. Retrieved fromhttp://publication.pravo.gov.ru/Document/View/0001201808030066

Ryan, M., H., Chilvers, G. A., \& Dumaresq, D. C. (1994). Colonisation of wheat by VA-mycorrhizal fungi was found to be higher on a farm managed in an organic manner than on a conventional neighbour. Plant and Soil, 160, 33-40. https://doi.org/10.1007/BF00150343 
Saha, R., Chaudhary, R. S., \& Somasundaram, J. (2012). Soil health management under hill agroecosystems of North East India. Applied and Environmental Soil Science, 2012, 1-9. https://doi.org/10.1155/2012/696174

Salonen, J., \& Ketoja, E. (2019). Undersown cover crops have limited weed suppression potential when reducing tillage intensity in organically grown cereals. Organic Agriculture. https://doi.org/10.1007/s13165-019-00262-6

Santos, C. A. D., Krawulski, C. C., Bini, D., Filho, T. G., Knob, A., Medina, C. C., Filho, G. A., \& Nogueira, M. A. (2015). Reclamation status of a degraded pasture based on soil health indicators. Scientia Agricola, 72(3), 195-202. http://dx.doi.org/10.1590/0103-9016-2013-0274

Saranraj, P., \& Stella, D. (2012). Vermicomposting and its importance in improvement of soil nutrients and agricultural crops. Novus Natural Science Research, 1(1), 14-22.

Schonbeck, M., Jerkins, D., \& Ory, J. (2017). Soil health and organic farming: Building organic matter for healthy soils. An overview. Organic farming research foundation. Santa Cruz. CA. pp. 5-15.

Seufert, N., Ramankutty, N., \& Foley, J. A. (2012). Comparing the yields of organic and conventional agriculture. Nature, 485(7397), 229-32. http://dx.doi.org/10.1038/nature11069

Shepherd, M. A., Rayns, F., \& Price, P. N. (2006). Soil and nutrient management on organic farms. Department for Environment, Food and Rural Affairs, United Kingdom. pp. 6-10. http://dx.doi.org/10.13140/2.1.3331.9684

Smith, L. G., Kirk, G. J. D., Jones, P. J. (2019) The greenhouse gas impacts of converting food production in England and Wales to organic methods. Nature Communications, 10, 4641 http://dx.doi.org/10.1038/s41467-019-12622-7

Soumya, K. M. (2015). Organic farming: An effective way to promote sustainable agriculture development in India. IOSR Journal of Humanities and Social Science, 20(6), 31-36. http://dx.doi.org/10.9790/0837-20643136

Srinivasa, R., Venkateswarlu, B., Babu, M. D., Wani, S. P., Dixit, S., Sahrawat, K. L., \& Kundu, S. (2011). Soil health improvement with Gliricidiagreen leaf manuring in rain fed agriculture on farm experience. Central research institute for dryland agriculture (ICAR) India. Technical Report, pp. 1-14.

TanCert Short Standards. (2003). Organic standards for agriculture production. Tanzania organic certification association. pp. 5-12. Retrieved fromhttp://www.grolink.se/epopa/Publications/TZshortstandard.pdf

Tejada, M., Hernandez, M. T., \& Garcia, C. (2006). Application of two organic amendments in soil restoration: Effects on soil biological properties. Journal of Environmental Quality, 35(4), 1010-7. http://dx.doi.org/10.1016/j.eja.2006.01.007

Tilak, K. V. B. R., Ranganayaki, N., Pal, K. K., Saxena, A. K., Nautiyal, C. S., Mittal, S., Tripathi, A. K., \& Johri, B. N. (2005). Diversity of plant growth and soil health supporting bacteria. Current Science, 89(1), 136-150.

Timsina, J. (2018). Can organic sources of nutrients increase crop yields to meet global food demand: A review. Agronomy, 8, 214. http://dx.doi.org/10.3390/agronomy8100214

Torsvik, V., \& Ovreas, L. (2002). Microbial diversity and functions in soil: From genes to ecosystems. Current Opinion in Microbiology, 5, 240-245. http://dx.doi.org/10.1016/S1369-5274(02)00324-7

Uganda Organic Standards for Organic Production and Processing (2006). pp. 34-35.

USDA (2008). Soil quality physical indicators: Selecting dynamic soil properties to assess soil function. Natural resources conservation service. Soil Quality Technical Note 10. Retrieved from https://www.nrcs.usda.gov/Internet/FSE_DOCUMENTS/nrcs142p2_050948.pdf

Vogl, C. R., Kilcher, L., \& Schmidt, H. (2005) Are standards and regulations of organic farming moving away from small farmer's knowledge? Research, reviews, practices, policy and technology. Journal of Sustainable Agriculture, 26(1), 5-26. http://dx.doi.org/10.1300/J064v26n01_03

Wander, M. (2019). Managing manure fertilizers in organic systems. Retrieved from https://eorganic.org/node/3132

Wang, P., Changa, C. M., Watson, M. E., Dick, W. A., Chen, Y., \& Hoitink, H. A. J. (2004). Maturity indices for composted dairy and pig manures. Soil Biology and Biochemistry, 36, 767-776.

http://dx.doi.org/10.1016/j.soilbio.2003.12.012 
Wiseman, P. E., Day, S. D., \& Harris, J. R. (2012). Organic amendment effect on soil carbon and microbial biomass in the root zone of three landscape tree species. Arboriculture and Durban Forestry, 38(6), 262-276.

Whalen, J. K., Chang, C., Clayton, G. W., \& Carefoot, J. P. (2000). Cattle manure amendments can increase the $\mathrm{pH}$ of acid soils. Soil Science Society America Journal, 64, 962-966. https://doi.org/10.2136/sssaj2000.643962x

Whalen, J. K., Chang C., \& Olson, B. M. (2001). Nitrogen and phosphorus mineralization potentials of soil receiving repeated annual cattle manure application. Biology and Fertility of Soils, 34, 334-341. http://dx.doi.org/10.1007/s003740100416

Wortman, S. E., Wortmann, C. S., Pine, A. L., Shapiro, C. A., Thompson, A. A., \& Little, R. S. (2017). Nutrient management in organic farming. NebGuide. Nebraska Extension, pp. 1-7.

Zikeli, S., Deil, L., \& Moller, K. (2017). The challenge of imbalanced nutrient flows in organic farming systems: A study of organic greenhouses in Southern Germany. Agriculture, Ecosystems and Environment, 244, 1-13. http://dx.doi.org/10.1016/j.agee.2017.04.017

\section{Copyrights}

Copyright for this article is retained by the author(s), with first publication rights granted to the journal.

This is an open-access article distributed under the terms and conditions of the Creative Commons Attribution license (http://creativecommons.org/licenses/by/3.0/). 